\title{
Assessment of quality and viability of primed maize seed
}

\author{
Gordana Tamindžić ${ }^{* 1}$ - Maja Ignjatov ${ }^{1}$ - Dragana Milošević ${ }^{1}$ Zorica Nikolić ${ }^{1}$. \\ Aleksandra Nastasić ${ }^{1}$. Dušica Jovičić - Jasna Savić ${ }^{2}$ \\ 1 Institute of Field and Vegetable Crops, Maksima Gorkog 30, 21000 Novi Sad, Serbia \\ ${ }^{2}$ University of Novi Sad, Faculty of Agriculture, Nemanjina 6, 11080 Belgrade-Zemun, Serbia
}

\begin{abstract}
Summary: Good crop establishment is essential for achieving high yield and constraints to good establishment include untimely sowing and low seed quality combined with various adverse growing conditions after sowing. Seed priming is a pre-sowing technique used for the improvement of germination, reduction of the time from sowing to emergence and improvement of emergence uniformity. Various seed priming techniques, such as hydropriming and priming with zinc, are used nowadays to improve crop establishment. The importance of seed priming with zinc for better germination, improved stand establishment, and higher maize yield are well documented. However, there is still a lack of results on the effects of seed priming with water and zinc on seed quality and viability, given that maize seed can be kept in storage for many years without a significant reduction in germination. The study was aimed to evaluate the effects of seed priming with water and $Z_{n}$ on the quality and viability of the maize seed. In order to evaluate the response of four maize hybrids to priming with water (hydropriming) and $4 \mathrm{mM}$ zinc sulphate, primed seeds were subjected to laboratory tests, namely to the germination test, the cold test, and the accelerated aging test. Both priming treatments increased the seed quality, but the beneficial effect of Zn-priming maintained to a larger extent than hydropriming in cold-treated and aged seeds. The negative effects of hydropriming on the viability of the aged seed of hybrid NS 4023 imply a possible limitation to deferred sowing of primed maize seed.

Key words: hydropriming, maize, seed quality, seed viability, Zn-priming
\end{abstract}

\section{Introduction}

The period from sowing to crop establishment is crucial for plant growth, due to its direct impact on yield and quality. Seed priming is a pre-sowing technique used for the improvement of germination, reduction of the time from sowing to emergence and improvement of emergence uniformity (Girolamo \& Barbanti, 2012). The purpose of seed priming is partial hydration of the seeds to a point when pre-germination metabolic processes are initiated but not completed (Mabhaudhi \& Modi, 2011). Various seed priming

\section{Corresponding author}

gordana.tamindzic@ifvens.ns.ac.rs

Acknowledgements:

This research was supported by the Ministry of Education, Science and Technological Development of the Republic of Serbia, grant number: 451-0368/2020-14/200032

\section{Cite this article:}

Tamindžić G., Ignjatov M., Milošević D., Nikolić Z., Nastasić A., Jovičić D., Savić J. (2020). Assessment of quality and viability of primed maize seed. Ratar Pount, $57(3), 87-92$. techniques, such as hydropriming, osmopriming, halopriming, nutrient priming, matri-priming, and hormonal-priming are used nowadays to improve crop establishment under different field conditions (Girolamo \& Barbanti, 2012). Additionally, seed priming improves stress tolerance in maize (Čanak et al., 2016).

It is well documented that seed priming with water can cause substantial increase of maize yield, germination, and seedling emergence under stressful conditions such as low temperature and limited water supply (Harris et al., 2007; Canak et al., 2016). Nutrient seed priming is a technique in which seeds are soaked in a nutrient solution instead of pure water to increase seed nutrient content in addition to the priming effect of water on improved seed quality for better germination and seedling establishment (Imran et al., 2013). Also, using seeds with elevated micronutrient content improves seedling vigour and yield increase in different crops. The importance of seed priming with micronutrients such as zinc ( $\mathrm{Zn}$ ) for improved germination, stand establishment, subsequent growth and yield has been reported in maize, wheat (Rehman et al., 2015; Harris et al., 2007) and other crops. Zinc has 
an important physiological role in protein metabolism, the structural and functional integrity of biomembranes, photosynthetic metabolism and indoleacetic acid (IAA) metabolism in seeds, plant cell protection from damage by reactive oxygen species, etc. (Cakmak, 2000).

Yet, there is a lack of information on the effect of priming techniques on seed quality and viability. The results obtained in studies with seed priming vary depending on species, seed quality, procedure parameters, germination conditions, etc. (Girolamo \& Barbanti, 2012). Reports also imply limited duration of storage of primed seeds (Paparella et al., 2015). Maize seed can be kept in storage for many years without a significant reduction in germination, but the reduction of primed seeds longevity during storage may limit the effectiveness of priming applied.

The study was aimed to examine the effectiveness of seed priming with $\mathrm{Zn}$ and water on maize seed quality and viability under optimal and stressful conditions. Laboratory tests were conducted for this purpose, the germination test, the cold test, and the accelerated aging test.

\section{Material and Methods}

\section{Plant material and priming treatments}

Seeds of maize hybrids NS 6030, NS 4030, NS 4023, and NS 3022 were obtained from the Maize Department of the Institute of Field and Vegetable Crops, Novi Sad, Serbia. Seeds of maize hybrids were produced in 2014 at the same locations at the Institute of Field and Vegetable Crops, Novi Sad. Seeds of all hybrids were primed with distilled water (hydropriming) or $4 \mathrm{mM} \mathrm{ZnSO}_{4}$ water solution, and non-primed seeds were used as control. A total of 60 maize seeds were primed in $200 \mathrm{ml}$ of distilled water and $4 \mathrm{mM}$ zinc sulphate solution for 24 hours in the dark, respectively, as described by Imran et al. (2013). Afterward, Znprimed seeds were rinsed thoroughly with distilled water for one minute to remove the priming solution. All treated seeds were air-dried close to the original weight. Samples were air-dried and milled to obtain the $\mathrm{Zn}$ concentration of Zn-primed seeds.

\section{Laboratory testing}

Seed germination and seedling growth of maize, as well as seed viability, were examined using the germination test, the cold test and the accelerated aging test in 2015. The working sample consisted of $4 \times 100$ seeds which were randomly selected. Four replications per treatment were arranged in a randomized block design. Primed seeds, as well as control, were subjected to laboratory tests. In the germination test, sterile sand was used as the substrate. Seeds were incubated in the germination chamber at $25^{\circ} \mathrm{C}$. The final seed germination (FG) and the percentage of abnormal seedlings (AS) were determined seven days after sowing according to ISTA (2015). In the cold test, seeds were sown in a mixture of soil and sand. The samples were exposed to $7^{\circ} \mathrm{C}$ for seven days and afterward placed in the germination chamber at $25^{\circ} \mathrm{C}$ for six days (Hampton \& TeKrony, 1995). In the accelerated aging test, seeds were exposed to a high temperature $\left(42^{\circ} \mathrm{C}\right)$ and high relative humidity $(100 \%)$ for 96 hours. After this period, seeds were sown in the sterile sand as described in the germination test (ISTA, 2015).

For measurement of seedling length, ten normal seedlings per each replicate were placed at the moistened filter paper for seven days. Ten normal seedlings were oven-dried at $80^{\circ} \mathrm{C}$ to constant weight to obtain seedling dry weight (SDW).

\section{Analytical methods}

For determination of $\mathrm{Zn}$ concentration in primed seeds, $0.5 \mathrm{~g}$ of dry samples was microwave digested with $10 \mathrm{ml}$ of $\mathrm{HNO}_{3}+2 \mathrm{ml} \mathrm{H} \mathrm{O}_{2}$ (Milestone ETHOS UP, Milstone Inc., Shelton, USA). Samples were analyzed for $\mathrm{Zn}$ by Inductively Coupled Plasma Optical Emission Spectroscopy (ICP-OES, Vista Pro, Varian, and ICP-OES; SpectroGenesis EOP II, Spectro Analytical Instruments $\mathrm{GmbH}$, Kleve, Germany).

\section{Statistical analyses}

In order to examine the difference between tested treatments within a single sample, data were subjected to the one-way analysis of variance (one-way ANOVA) and Duncan's multiple range test $(p<0.05)$ using the software Statistica 10.

\section{Results and discussion}

For four tested maize hybrids, $\mathrm{Zn}$ concentration in seeds primed with $\mathrm{ZnSO}_{4}$ was $298.1 \mathrm{mg} \mathrm{kg}^{-1}, 361.0 \mathrm{mg}$ $\mathrm{kg}^{-1}, 333.5 \mathrm{mg} \mathrm{kg}^{-1}$, and $257.6 \mathrm{mg} \mathrm{kg}^{-1}$ (in order as presented in tables) and it was significantly increased in comparison to untreated seeds (results not shown). The final seed germination of hybrids ranged from $93.0 \%$ to $96.3 \%$ under optimal conditions of the germination test (Table 1). The results clearly showed significant effects of priming treatments on maize hybrid seed performance, but there was no clear pattern in their response to treatments. In comparison to control, the final germination significantly increased whilst the occurrence of abnormal seedlings significantly decreased in hybrids NS 6030 and NS 3022 by both priming treatments. According to Basra et al. (2002), the positive effects of hydropriming can be attributed to the underlying physiological background of the treatment, which is the increased metabolic activity in seeds. Enzymes involved in the mobilization of stored protein are either synthesized or activated during seed priming (Varier et al., 2010). Moreover, similar results were obtained by Mir-Mahmoodi et al. (2011) on maize seed primed with $\mathrm{Zn}$, emphasizing that $\mathrm{ZnSO}_{4}$ had no phytotoxic effects due to ion accumulation in the embryo. Cellular mechanisms of seed priming related to 
improving germination and increasing tolerance to stress conditions have not been fully understood (Chen \& Arora, 2013). Overall research to date has stated that seed priming regulates the level of signalling molecules and phytohormones during germination and has an effect on later plant development (Wojtyla et al., 2016).

Furthermore, positive significant effects of both treatments were obtained for root and shoot length, whilst differences between treatments were less pronounced for the shoot. For instance, the highest root length increase of $46 \%$ relative to control was obtained in NS 6030 by Zn-priming (Table 1). Both priming treatments significantly enhanced seedling dry biomass accumulation in NS 4023 and NS 3022, whilst only Znpriming had this effect in NS 6030 and NS 4030 . Moreover, the additional effect of $\mathrm{Zn}$ was recorded in NS 3022, due to seedling dry weight relative increase of $18 \%$ in comparison with hydropriming, which is in accordance with the results obtained on maize by MirMahmoodi et al. (2011). Also, Imran et al. (2017) established a positive effect of $\mathrm{Zn}$ seed priming on seedling biomass accumulation of maize.

Table 1. Effects of hydropriming and Zn-priming on germination and seed quality of maize hybrids

\begin{tabular}{clccccc}
\hline Hybrids & Priming treatments & FG $(\%)$ & AS $(\%)$ & SL (mm) & RL (mm) & SDW (g) \\
\hline \multirow{3}{*}{ NS 6030 } & Control & $94.8 \mathrm{~b}$ & $3.3 \mathrm{a}$ & $122 \mathrm{~b}$ & $140 \mathrm{c}$ & $0.53 \mathrm{~b}$ \\
& Hydropriming & $97.3 \mathrm{a}$ & $1.5 \mathrm{~b}$ & $160 \mathrm{a}$ & $178 \mathrm{~b}$ & $0.59 \mathrm{~b}$ \\
& Zn-priming & $98.3 \mathrm{a}$ & $0.8 \mathrm{~b}$ & $160 \mathrm{a}$ & $205 \mathrm{a}$ & $0.90 \mathrm{a}$ \\
\hline \multirow{3}{*}{ NS 4030 } & Control & $93.0 \mathrm{a}$ & $5.3 \mathrm{a}$ & $158 \mathrm{~b}$ & $154 \mathrm{~b}$ & $0.49 \mathrm{~b}$ \\
& Hydropriming & $95.5 \mathrm{a}$ & $3.0 \mathrm{a}$ & $176 \mathrm{a}$ & $182 \mathrm{a}$ & $0.53 \mathrm{~b}$ \\
& Zn-priming & $92.3 \mathrm{a}$ & $6.0 \mathrm{a}$ & $184 \mathrm{a}$ & $202 \mathrm{a}$ & $0.72 \mathrm{a}$ \\
\hline \multirow{3}{*}{ NS 4023 } & Control & $94.8 \mathrm{a}$ & $4.3 \mathrm{a}$ & $118 \mathrm{a}$ & $160 \mathrm{c}$ & $0.61 \mathrm{~b}$ \\
& Hydropriming & $92.8 \mathrm{a}$ & $3.5 \mathrm{a}$ & $116 \mathrm{a}$ & $182 \mathrm{~b}$ & $0.71 \mathrm{a}$ \\
& Zn-priming & $93.3 \mathrm{a}$ & $4.3 \mathrm{a}$ & $117 \mathrm{a}$ & $201 \mathrm{a}$ & $0.76 \mathrm{a}$ \\
\hline \multirow{3}{*}{ NS 3022 } & Control & $96.3 \mathrm{~b}$ & $2.25 \mathrm{a}$ & $128 \mathrm{~b}$ & $156 \mathrm{~b}$ & $0.76 \mathrm{c}$ \\
& Hydropriming & $99.0 \mathrm{a}$ & $1.00 \mathrm{~b}$ & $141 \mathrm{a}$ & $187 \mathrm{a}$ & $0.88 \mathrm{~b}$ \\
& Zn-priming & $98.3 \mathrm{a}$ & $1.25 \mathrm{~b}$ & $150 \mathrm{a}$ & $197 \mathrm{a}$ & $1.04 \mathrm{a}$ \\
\hline
\end{tabular}

*FG-final germination, AS-abnormal seedlings, SL-shoot length, RL-root length, SDW-seedling dry weight. Presented data are means (n=4). Different letters denote significant differences between priming treatments compared by Duncan's multiple range test $(p<0.05)$.

Table 2. Effects of hydropriming and Zn-priming on germination and vigour of cold-treated seeds of maize hybrids

\begin{tabular}{llccccc}
\hline Hybrids & Priming treatments & FG $(\%)$ & AS $(\%)$ & SL (mm) & RL (mm) & SDW (g) \\
\hline \multirow{3}{*}{ NS 6030 } & Control & $92.7 \mathrm{a}$ & $3.25 \mathrm{~b}$ & $96 \mathrm{a}$ & $115 \mathrm{~b}$ & $0.47 \mathrm{c}$ \\
& Hydropriming & $81.0 \mathrm{~b}$ & $8.00 \mathrm{a}$ & $102 \mathrm{a}$ & $113 \mathrm{~b}$ & $0.53 \mathrm{~b}$ \\
& Zn-priming & $93.5 \mathrm{a}$ & $4.00 \mathrm{~b}$ & $101 \mathrm{a}$ & $125 \mathrm{a}$ & $0.65 \mathrm{a}$ \\
\hline \multirow{3}{*}{ NS 4030 } & Control & $84.0 \mathrm{a}$ & $8.75 \mathrm{a}$ & $96 \mathrm{~b}$ & $126 \mathrm{a}$ & $0.38 \mathrm{a}$ \\
& Hydropriming & $69.5 \mathrm{~b}$ & $7.75 \mathrm{a}$ & $82 \mathrm{c}$ & $100 \mathrm{~b}$ & $0.39 \mathrm{a}$ \\
& Zn-priming & $71.8 \mathrm{~b}$ & $4.25 \mathrm{~b}$ & $112 \mathrm{a}$ & $122 \mathrm{a}$ & $0.42 \mathrm{a}$ \\
\hline \multirow{3}{*}{ NS 4023 } & Control & $86.5 \mathrm{a}$ & $8.00 \mathrm{a}$ & $94 \mathrm{a}$ & $140 \mathrm{a}$ & $0.52 \mathrm{~b}$ \\
& Hydropriming & $85.5 \mathrm{a}$ & $7.00 \mathrm{a}$ & $98 \mathrm{a}$ & $123 \mathrm{~b}$ & $0.52 \mathrm{~b}$ \\
& Zn-priming & $86.0 \mathrm{a}$ & $4.00 \mathrm{~b}$ & $103 \mathrm{a}$ & $141 \mathrm{a}$ & $0.64 \mathrm{a}$ \\
\hline \multirow{2}{*}{ NS 3022 } & Control & $94.5 \mathrm{a}$ & $0.00 \mathrm{~b}$ & $90 \mathrm{~b}$ & $126 \mathrm{a}$ & $0.64 \mathrm{a}$ \\
& Hydropriming & $94.0 \mathrm{a}$ & $3.50 \mathrm{a}$ & $100 \mathrm{ab}$ & $116 \mathrm{~b}$ & $0.58 \mathrm{a}$ \\
\hline
\end{tabular}

*FG-final germination, AS-abnormal seedlings, SL-shoot length, RL-root length, SDW-seedling dry weight. Presented data are means (n=4). Different letters denote significant differences between priming treatments compared by Duncan's multiple range test ( $\rho<0.05$ ). 
Table 3. Effects of hydropriming and Zn-priming on germination and vigour of aged seeds of maize hybrids

\begin{tabular}{llccccc}
\hline Hybrids & Priming treatments & FG $(\%)$ & AS $(\%)$ & SL (mm) & RL (mm) & SDW (g) \\
\hline \multirow{3}{*}{ NS 6030 } & Control & $96.3 \mathrm{a}$ & $1.75 \mathrm{~b}$ & $141 \mathrm{a}$ & $165 \mathrm{~b}$ & $0.71 \mathrm{a}$ \\
& Hydropriming & $93.5 \mathrm{a}$ & $4.50 \mathrm{a}$ & $133 \mathrm{a}$ & $164 \mathrm{~b}$ & $0.54 \mathrm{~b}$ \\
& Zn-priming & $94.5 \mathrm{a}$ & $5.00 \mathrm{a}$ & $136 \mathrm{a}$ & $187 \mathrm{a}$ & $0.68 \mathrm{a}$ \\
\hline \multirow{3}{*}{ NS 4030 } & Control & $92.3 \mathrm{a}$ & $6.25 \mathrm{a}$ & $156 \mathrm{a}$ & $135 \mathrm{c}$ & $0.45 \mathrm{~b}$ \\
& Hydropriming & $91.5 \mathrm{a}$ & $4.25 \mathrm{a}$ & $160 \mathrm{a}$ & $152 \mathrm{~b}$ & $0.43 \mathrm{~b}$ \\
& Zn-priming & $91.8 \mathrm{a}$ & $5.50 \mathrm{a}$ & $161 \mathrm{a}$ & $174 \mathrm{a}$ & $0.52 \mathrm{a}$ \\
\hline \multirow{2}{*}{ NS 4023 } & Control & $95.8 \mathrm{a}$ & $3.00 \mathrm{~b}$ & $137 \mathrm{a}$ & $161 \mathrm{a}$ & $0.70 \mathrm{a}$ \\
& Hydropriming & $71.5 \mathrm{~b}$ & $11.50 \mathrm{a}$ & $106 \mathrm{~b}$ & $145 \mathrm{~b}$ & $0.57 \mathrm{~b}$ \\
& Zn-priming & $75.8 \mathrm{~b}$ & $4.75 \mathrm{~b}$ & $110 \mathrm{~b}$ & $156 \mathrm{a}$ & $0.72 \mathrm{a}$ \\
\hline \multirow{2}{*}{ NS 3022 } & Control & $90.3 \mathrm{a}$ & $5.50 \mathrm{a}$ & $120 \mathrm{a}$ & $156 \mathrm{a}$ & $0.72 \mathrm{~b}$ \\
& Hydropriming & $88.5 \mathrm{a}$ & $7.00 \mathrm{a}$ & $112 \mathrm{~b}$ & $129 \mathrm{~b}$ & $0.66 \mathrm{~b}$ \\
& Zn-priming & $88.0 \mathrm{a}$ & $6.25 \mathrm{a}$ & $118 \mathrm{a}$ & $157 \mathrm{a}$ & $0.89 \mathrm{a}$ \\
\hline
\end{tabular}

*FG-final germination, AS-abnormal seedlings, SL-shoot length, RL-root length, SDW-seedling dry weight. Presented data are means (n=4). Different letters denote significant differences between priming treatments compared by Duncan's multiple range test $(p<0.05$ ).

Priming treatments had no significant effect on germination of hybrids NS 4023 and NS 3022 in coldtreated seeds, whilst germination was significantly lower in both treatments and hydropriming than in control for NS 4030 and NS 6030, respectively (Table 2). Mabhaudhi \& Modi (2011) obtained similar results, stating that the reason for the decrease in seed germination rate is a rapid water uptake during priming, which can cause injury during imbibition, to impede seed germination. In contrast to the results obtained for the germination test, Zn-priming significantly decreased the occurrence of abnormal seedlings for hybrids NS 4030 and NS 4023, whilst it was opposite for NS 6030 and NS 3022. Ozturk et al. (2006) highlighted the involvement of zinc in physiological processes during the initial shoot development, possible involvement in protein synthesis, cell elongation, membrane functions, and resistance to abiotic stress. Furthermore, promoted shoot and root growth by Zn-priming resulted in a significant increase of seedling dry weight for NS 6030 and NS 4023. Seed priming enhances process during germination. It is also involved in specific mechanisms that improve seed viability and helps shoots cope with stressful conditions, thus increasing antioxidant activity (Hussain et al., 2016). As a result, plants have better growth and biomass accumulation. Furthermore, Imran (2012) stated that temperatures below $15^{\circ} \mathrm{C}$ significantly reduce maize dry root biomass and limit nutrient uptake. Zinc has the role in direct stabilization of membranes, and biosynthesis of auxins and gibberellins involved in regulating plant growth and protein synthesis as a whole. The author also stated that a limited amount of zinc under low-temperature conditions can increase oxidative damage to root cells and cause disruption of plant growth, which can be mitigated by seed priming. Zinc seed priming results in improved plant growth and biomass accumulation of maize (Imran et al., 2013), which is in accordance with the results of this study.

According to the obtained results, beneficial effects of both priming treatments on germination and the occurrence of abnormal seedlings were not recorded for aged seeds of the examined hybrids (Table 3). All measured parameters of NS 4023 were negatively affected by hydropriming in comparison to control, whilst the occurrence of abnormal seedlings of NS 6030 was significantly increased by both treatments. Varier et al. (2010) stated that highly vigorous seed lots are endangered after priming, which is in accordance with the presented results. In general, seed priming improves longevity of low-vigor seeds, while longevity decreases in high-vigor seeds (Pandita \& Nagarajan, 2000). Also, Varier et al. (2010) pointed out that damages to membranes and other subcellular components, caused by harmful free radicals produced by peroxidation of the unsaturated and polyunsaturated fatty acids of the membrane, are cited as the most common cause of seed deterioration. Harmful free radicals are quenched or converted to less harmful products, such as hydrogen peroxide or water by free radical scavenging enzymes and antioxidants. Ventura et al. (2012) stated that the repair of DNA damage during seed aging, storage, and seed rehydration should be considered as the most significant and most valuable process activated during seed priming, indicating its benefits. Despite all the advantages of the priming technique, Zn-priming resulted in reduced germination percentage in NS 4023 in the accelerated aging test. The results can be explained by the fact that seed priming can have positive results only in cases where cellular damage is not irreversible (Butler et al., 2009). Moreover, seedling dry weight of all hybrids was significantly lower in hydropriming treatment than in control, whilst opposite results were obtained by Zn- 
priming for NS 4030 and NS 3022. Once again, the results indicate the involvement of $\mathrm{Zn}$ in many physiological processes during early plant development, as well as its involvement in plant resistance to stress conditions, which is in accordance with the findings by Farooq et al. (2012) and Cakmak (2010).

\section{Conclusion}

Depending on germination conditions, our results showed positive effects of priming treatments on maize seed germination and initial maize growth, although a clear pattern was not established due to the genetic specificity of the tested maize hybrids. Maize seeds primed with Zn had better initial plant growth and dry biomass accumulation than other treatments. However, the accelerated aging test indicated that deferred sowing of primed seeds might lead to reduced germination and field emergence. Further research should be conducted to determine genotypic differences in quality and viability of seeds primed with water and $\mathrm{Zn}$ under different conditions, in terms of seed physiology, hydration process, and zinc localization in the seed, as well as evaluation of Serbian maize germplasm to $\mathrm{Zn}$ efficiency.

\section{References}

Basra, S. M. A., Zia, M. N., Mehmood, T., Afzal, I., Khaliq, A. (2002). Comparison of different invigoration techniques in wheat (Triticum aestivum L.) seeds. Pakistan Journal of Anid Agriculture, 5, 11-16.

Butler, L. H., Hay, F. R, Ellis, R. H, Smith, R. D., Murray, T. B. (2009). Priming and re-drying improve survival of mature seeds of Digitalis purpurea during storage. Annals of Botany, 103, 1261-1270. https:// dx.doi.org $/ 10.1093 \% 2 \mathrm{Faob} \% 2 \mathrm{Fmcp} 059$

Cakmak, I. (2000). Possible roles of zinc in protecting plant cells from damage by reactive oxygen species. The Nem Phytologist, 146, 185-205. https://doi.org/10.1046/j.1469-8137.2000.00630.x

Cakmak, I., Kalayci, M., Kaya, Y., Torun, A. A., Aydin, N., Wang, Y., Arisoy, Z., Erdem, H., Yazici, A, Gokmen, O. L. O., Horst, W. J. (2010). Biofortification and localization of zinc in wheat grain. Joumal of Agricultural and Food Chemistry, 58, 9092-9102. doi: $10.1021 / \mathrm{f} 101197 \mathrm{~h}$

Chen, K, Arora, R (2013). Priming memory invokes seed stresstolerance. Emirommental and Expenimental Botany, 94, 33-45. https:// doi.org/10.1016/j.envexpbot.2012.03.005

Canak, P., Mirosavljević, M., Cirić, M., Vujošević, B., Kešelj, J., Stanisavljević, D., Mitrović, B. (2016). Seed priming as a method for improving maize seed germination parameters at low temperatures. Ratarstio i povtarstio, 53(3), 106-110. doi:10.5937/ratpov53-10825

Girolamo, G. D., Barbanti, L. (2012). Treatment conditions and biochemical processes influencing seed priming effectiveness. Itakian Joumal of Agronomy, 7, 178-188. https://doi.org/10.4081/ ija.2012.e25

Hampton, J. G., TeKrony, D. M. (1995). Handbook of V igour Test Methods. International Seed Testing Association.

Harris, D., Rashid, A., Miraj, G., Arif, M., Shah, H. (2007). On-farm seed priming with zinc sulphate solution, a cost effective way to increase maize yields of resource poor farmers. Field Crops Research, 11, 119127. https://doi.org/10.1016/j.fer.2007.03.005

Hussain, S., Khan, F., Hussain, H. A., Nie, L. (2016). Physiological and biochemical mechanisms of seed priming-induced chilling tolerance in rice cultivars. Frontiers in Plant Science, 7(116), 1-14. doi: 10.3389/ fpls. 2016.00116
Imran, M., Garbe-Schönberg, D., Neumann, G., Boelt, B., Mühling; K. H. (2017). Zinc distribution in primed maize seed and its translocation during early seedling development. Emirommental and Experimental Botamy, 143, 91-98. https://doi.org/10.1016/ j.envexpbot.2017.09.001

Imran, M., Mahrnood, A., Römheld, V., Neumann, G. (2013). Nutrient seed priming improves seedling development of maize exposed to low root zone temperatures during early growth. European Joumal of Agronomy, 49, 141-148. https://doi.org/10.1016/j.eja.2013.04.001

Inran, M. (2012): Nutrient Seed Priming Improves Abiotic Stress Tolerance in Zea mays $L$ and Glyine max $L$ Doctoral Dissertation, University of Hohenheim, Faculty of Agricultural Sciences, Germany.

ISTA (2015). International Rules for Seed Testing. Seed Science and Technology. Zurich, Switzerland.

Mabhaudhi, T., Modi, A. T. (2011). Can hydropriming improve germination speed, vigour and emergence of maize landraces under water stress? Joumal of Agricultumal Science and Technology, B 1, 20-28.

Mir-Mahmoodi, T., Golezani, K. G., Habibi, D., Paknezhad, F., Ardekani, M. R. (2011). Effects of priming techniques on seed germination and seedlings emergence of maize (Zea mays L.). Joumal of Food, Agriculture and Emiromment, 9 (2), 413-415.

Ozturk, L., Yazici, M.A., Yucel, C., Torun, A., Cekic, C., Bagci, A., Ozkan, H., Braun, H. J., Sayers, Z., Cakmak, I. (2006). Concentration and localization of zinc during seed development and germination in wheat. Physiologia Plantarum, 128, 144-152. https://doi.org/10.1111/j.1399-3054.2006.00737.x

Pandita, V. K., Nagarajan, S. (2000). Osmopriming of fresh seed and its effect on accelerated ageing in Indian tomato (Lycopersicon esculentum) varieties. Indian Joumal of Agricultural Sciences, 70, 479-480.

Paparella, S., Araujo, S. S., Rossi, G., Wijayasinghe, M., Carbonera, D., Balestrazzi, A. (2015). Seed priming: state of the art and new perspectives. Plant Cell Reponts, 34, 1281-1293. https:// doi.org/10.1007/s00299-015-1784-y

Rehman, A., Farooq, M., Ahmad, R., Basra, S. M. A. (2015). Seed priming with zinc improves the germination and early seedling growth of wheat. Seed Science and Technology, 4, 262-268. https:// doi.org $/ 10.15258 /$ sst.2015.43.2.15

Varier, A., Vari, A. K, Dadlani, M. (2010). The subcellular basis of seed priming. Current Science, 99 (4), 450-456.

Ventura, L., Donà, M., Macovei, A., Carbonera, D., Buttafava, A., Mondoni, A. (2012). Understanding the molecular pathways associated with seed vigor. Plant Physiology and Biochemistry, 60, 196206. https://doi.org/10.1016/i.plaphy.2012.07.031

Woityla, L., Lechowska, K., Kubala, S., Ganczarska, M. (2016). Different modes of hydrogen peroxide action during seed germination. Frontiers in Plant Science, 7, 66. https:// doi.org $/ 10.3389 /$ fpls.2016.00066 


\section{Ocena kvaliteta i životne sposobnosti semena kukuruza nakon prajminga}

\section{Gordana Tamindžić · Maja Ignjatov · Dragana Milošević · Zorica Nikolić · Aleksandra Nastasić · Dušica Jovičić · Jasna Savić}

Sažetak: U današnje vreme, različite tehnike prajminga semena, kao što su hidroprajming i prajming semena cinkom, koriste se u cilju poboljšanja useva. Značaj tehnika prajminga u postizanju bolje klijavosti semena, poboljšanju useva i postizanju visokog prinosa kukuruza dobro je dokumentovana. Međutim, još uvek nedostaju rezultati o uticaju prajminga semena vodom i cinkom na kvalitet i životnu sposobnost semena, s obzirom da se seme kukuruza može čuvati u skladištu duži niz godina bez značajnog smanjenja klijavosti. Ovo istraživanje je sprovedeno sa ciljem da se ispita uticaj prajminga semena vodom i cinkom na kvalitet i životnu sposobnost semena kukuruza. Za procenu odgovora četiri hibrida kukuruza na prajming semena vodom i $4 \mathrm{mM}$ rastvorom cink-sulfata, seme je nakon prajminga podvrgnuto laboratorijskim testovima, testu klijavosti, hladnom testu i testu ubrzanog starenja. Oba tretmana prajminga semena su uticala na povećanje kvaliteta semena kukuruza, ali blagotvorni efekat prajminga semena cinkom se ispoljio $u$ većem stepenu od hidroprajminga u stresnim uslovima hladnog testa $\mathrm{i}$ testa ubrzanog starenja. Negativni efekti hidroprajminga na životnu sposobnost semena hibrida NS 4023 ukazuju na moguće ograničenje za odloženu setvu semena kukuruza nakon prajminga.

Ključne reči: kukuruz, kvalitet semena, prajming semena cinkom, prajming semena vodom, životna sposobnost semena

This article is distributed under the terms of the Creative Commons Attribution 4.0 International License (http://creativecommons.org/licenses/bv/4.0). which permits unrestricted use, distribution and reproduction in any medium, provided you give appropriate credit to the original author(s) and the source, provide a link to the Creative Commons license, and indicate if changes were made. 